\title{
Increased levels of circulating IL-10 in persons recovered from hepatitis $C$ virus (HCV) infection compared with persons with active HCV infection
}

\author{
Dorcas Ohui Owusu ${ }^{1 *}$, Richard Phillips ${ }^{2}$, Michael Owusu ${ }^{3}$, Fred Stephen Sarfo ${ }^{4}$ and Margaret Frempong ${ }^{5}$
}

\begin{abstract}
Objective: Approximately 70\% of all hepatitis C (HCV) infections develop chronic disease. Active or exacerbated chronic hepatitis $\mathrm{C}$ infection subsequently progress to liver disease. The role of T-cells secretions in achieving viral clearance is still not well understood. Thus, the current study was set to determine the relationship between the T cell cytokine profiles, biochemical parameters and persistent HCV infection or spontaneous recovery.

Results: Twenty-five percent (41/163) of the anti-HCV positive participants had recovered from HCV and had significantly higher concentration of IL-10 compared to those with active HCV infection $(P<0.012)$. Other circulating cytokines measured; IL-2, IFN gamma, TNF alpha, IL-5 and IL-17 were similar in both groups. Participants with active HCV infection had significantly higher aspartate transaminase (AST) (35 units) and alanine transaminase (46 units) compared to those in the recovered state $(P<0.001)$. Thus, serum levels of IL10 could be explored in larger prospective cohort study as a predictive marker of recovering from an active HCV infection.
\end{abstract}

Keywords: Hepatitis C virus, Cytokine, Spontaneous recovery

\section{Introduction}

Hepatitis is a leading cause of morbidity and mortality in developing countries. Majority of these liver diseases are known to be of viral origin of which hepatitis $C$ virus $(\mathrm{HCV})$ is the second highest viral causal agent. It is estimated that $0.5 \%$ to $3.5 \%$ of the world's population, representing 36-266 million people are infected with hepatitis C $[1,2]$. Out of all infected individuals, $54-80 \%$ result in chronic forms of hepatitis $\mathrm{C}$ and subsequently lead to severe acute liver inflammation and damage $[3,4]$.

HCV is distributed worldwide, but with uneven geographical spread [5]. In Africa, the overall

\footnotetext{
*Correspondence: owusu.dorcas@gcuc.edu.gh

1 Department of Medical Laboratory Technology, Garden City University

College (GCUC), P.O. Box 12775, Kumasi, Ghana

Full list of author information is available at the end of the article
}

sero-prevalence is estimated to be between 0 and $66 \%$ [5-14]. In Ghana, the prevalence of hepatitis C varies between 0.3 and $23.2 \%$ across different locations. [11, 15].

Chronic or active forms of hepatitis $\mathrm{C}$ infection is achieved through successful evasion of the body's immune surveillance system [16-18]. There is limited data on the immunopathology of HCV infection in the Sub-Saharan Africa. The few data available have been from relatively low endemic regions. T-cells are thought to play a role in active $\mathrm{HCV}$ infection or spontaneously recovering from it, but the mechanism by which the virus is able to maintain viral perseverance in more than $50 \%$ of exposed individuals is still not well understood. Thus, there is the need to determine biomarkers, including serum cytokines which contribute to immunopathogenesis of hepatitis $C$ virus infection and their capability to predict the outcome of $\mathrm{HCV}$ infection. The objective 
of the present study was to determine and analyse the relationship between the $\mathrm{T}$ cells cytokine profiles, biochemical parameters and persistence $\mathrm{HCV}$ infection or recovery using a single observation design.

\section{Main text \\ Methods \\ Study population/design}

The study employed cross-sectional observation design. The study population was derived from individuals who had tested for HCV positive based on a rapid serological assay test. These individuals were recruited from three different sites in Ghana; the Transfusion unit of Komfo Anokye Teaching Hospital, Obuasi municipality and Daboya community. We recalled 322 individuals using records obtained from the previous work which was carried out between 2013 and 2014 (unpublished). Komfo Anokye Teaching Hospital (KATH) is the second largest tertiary medical facility in Ghana. The Blood Transfusion Medicine Unit serves KATH and other health facilities in
Ashanti Region. Obuasi Municipality is a big cosmopolitan municipal in Ashanti region with varying intercultural background due to ongoing mining activities and an estimated population of 169,000 . Daboya community is a district capital with an estimated population of 6,510 in the Northern part of Ghana (Fig. 1).

\section{Inclusion and exclusion}

Participants who were 18 years and above who voluntarily gave written informed consent were included. Participants should not have initiated HCV treatment at the time of enrolment. Participants who refused to provide consent were excluded from the study.

\section{Consent and ethics}

Ethics approval was granted by the Kwame Nkrumah University of Science and Technology and the Komfo Anokye Teaching Hospital research ethics review committee (Reference; CHRPE/AP/134/13, CHRPE/ $\mathrm{AP} / 443 / 13$ and CHRPE/AP/162/15). Written consent

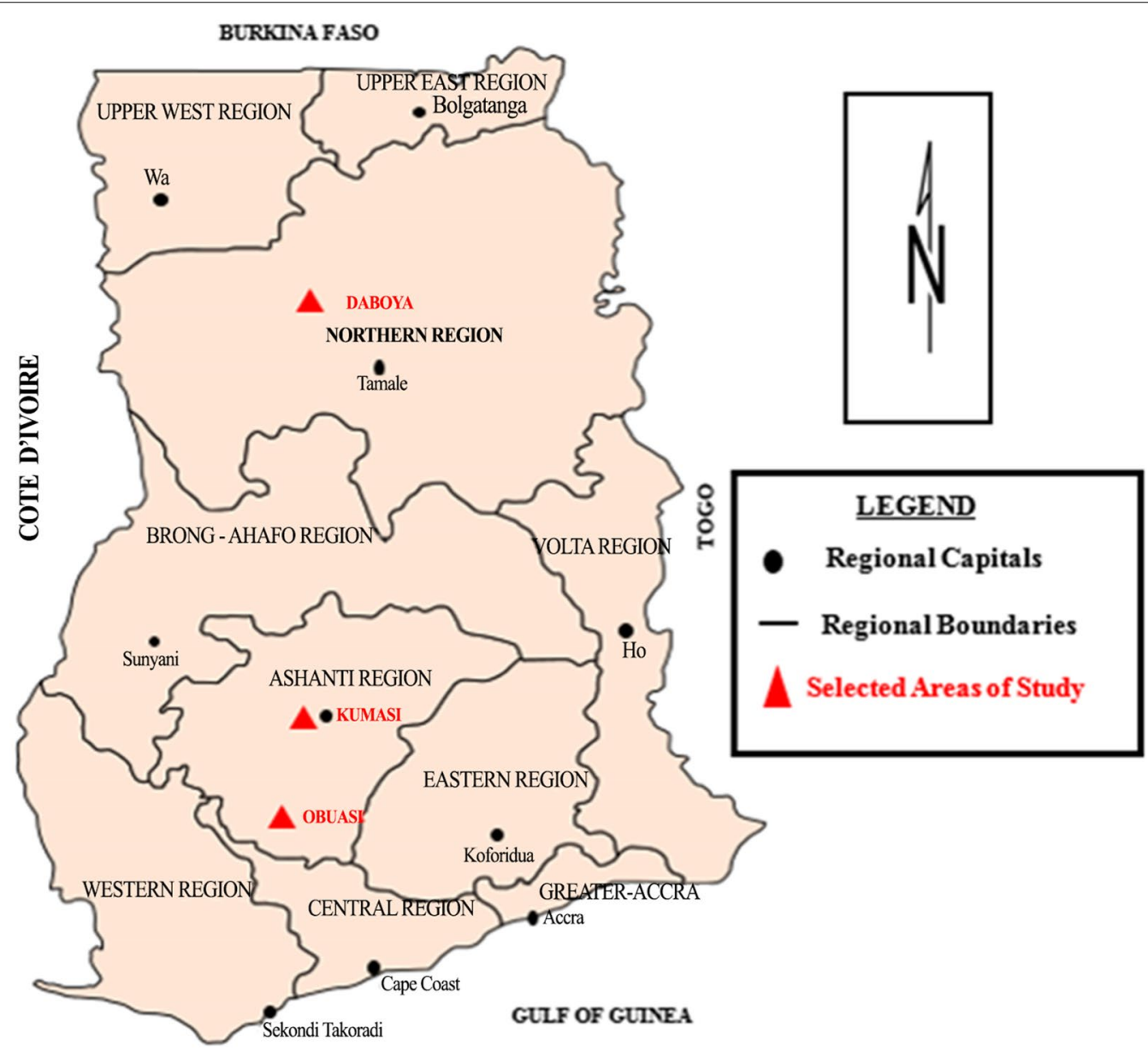

Fig. 1 Map of Ghana with selected areas of study. The map was adapted and modified from our previously published manuscript [44] 
was obtained from all participants above 18 years. Confidentiality of participant information was maintained at each level of the study.

\section{Sample collection and processing}

At least $5 \mathrm{ml}$ of venous blood samples were collected from all HCV seropositive participants. Blood were collected into EDTA and serum vacutainers, transported to the laboratory and further processed for serum.

\section{Anti-HCV screening confirmation}

All samples collected were further confirmed for $\mathrm{HCV}$ sero-positivity using $\mathrm{ORTHO}^{\circledR} \mathrm{HCV}$ Version 3.0 ELISA Test System (Ortho Clinicals Incorporated, USA) according to the manufacturer's protocol. The test determined antibodies to recombinant hepatitis $\mathrm{C}$ encoded antigens c22-3, c200 and NS5 regions which is precoated in microwell-plates.

\section{HCV quantification}

Samples that were confirmed to be anti-HCV positive were further tested for HCV RNA and quantified using the Abbott Real-time RT-PCR (Abbott, IL, USA) automated system according to the manufacturer's instructions.

\section{HBsAg screening and confirmation}

All the anti-HCV confirmed positive samples were serologically assessed for hepatitis B virus surface antibody (anti-HBsAg). The test assay was done using GS HBsAg EIA 3.0 (BIO-RAD, Redmond, Washington. USA) and according to the manufacturers protocol.

\section{HIV screening}

All the anti-HCV confirmed positive samples were further serologically assessed for HIV-1 and HIV-2 antigen and antibodies. The test assay was done using GS HIV Combo Ag/Ab EIA (BIO-RAD Clinical Diagnostic group, Redmond, Washington. USA) and according to the manufacturers protocol. The tests determined antigens and antibodies to HIV $1 \& 2$ using microwell-plates precoated with monoclonal antibodies to HIV p24 (mouse) and HIV-1 and HIV-2 antigens.

\section{Biochemical analysis}

Serum alanine aminotransferase (ALT) and aspartate aminotransferase (AST) levels were measured using ALT/GPT 4+1 SL (ELITech Clinical Systems) on Selectra ProS automated chemistry analyser (ELITech company, Japan) per protocol.

\section{Analysis of serum cytokines}

Samples from participants with known HCV status were analysed for their cytokine levels. The relative expression levels of $\mathrm{T}$ cell cytokines (Interleukin 2 (IL-2), Interferon (IFN) gamma, Tumour necrosis factor (TNF) alpha, Th2 (Interleukin 5 (IL-5), Th17 cytokines (Interleukin 17 (IL-17) and Interleukin 10 (IL-10) were determined. Cytokines were quantitated using commercially available ELISA assay (Affymetrix eBioscience ELISA Ready-SETGo, San Diego-California) according to the manufacturer's instructions. High protein binding ELISA plates were coated with specific capture monoclonal antibody to determine the cytokines (analytes) in the serum samples.

\section{Definitions for hepatitis C infection}

For purposes assessing the immunological and biochemical markers in hepatitis $C$, we classified our study subjects into recovered and active HCV states of infection. Subjects were considered recovered when the serological test was positive but HCV RNA was negative. Subjects were considered as having active $\mathrm{HCV}$ infections when the serological test and HCV RNA were both positive. These classifications were based on previous reports [19].

\section{Data collection and statistical analysis}

Socio-demographic information was collected through face-face interview with participants. The socio-demographic study variables determined were sex, age, use of alcohol and hepatitis B status. All categorical variables were analysed using Chi square test. Continuous variables and their subcategories were also analysed using either parametric or non-parametric methods based on the distribution of the variables. Statistical analyses were performed using IBM SPSS Statistics v.12 (IBM Computer hardware company, New York, USA) and $p$ value of $\leq 0.05$ was considered statistically significant.

\section{Results}

A total of 163 participants who agreed to participate in the study were confirmed to be HCV sero-positive. Of the 163, 97 (59.5\%) were from KATH, 38 (23.3\%) were from Obuasi and 28 (17.7\%) were from Daboya. Ninetyeight $(98 ; 60.1 \%)$ of the study subjects were males and 65 (39.9\%) were females. The overall mean age of participants was 36 . Table 1 shows the socio-demographic characteristics of participants.

Of the 163 seropositive participants, 122 (74.84\%; 95\% CI 67.46-81.30) had active HCV infection and 41 (25.15\%; 95\%CI $18.69-32.53)$ were in the recovery state. The mean hepatitis $C$ viral load of participants with active $\mathrm{HCV}$ infection was $5.5 \log _{10} \mathrm{IU} / \mathrm{ml}( \pm 1.0 \mathrm{IU})$. Table 2 shows a comparison of sex, age, HBsAg status, 
Table 1 Socio-demographic characteristics of participants

\begin{tabular}{lc}
\hline Total & $\mathbf{N}=\mathbf{1 6 3}$ \\
\hline Sex & $65(39.9)$ \\
Female n (\%) & $98(60.1)$ \\
Male n (\%) & \\
Age & $35.8(11.9)$ \\
Mean (SD) & \\
Occupation ${ }^{\text {a }}$ & $28(23)$ \\
Modern professional occupation n (\%) & $13(10.7)$ \\
Farming or agricultural occupation n (\%) & $36(29.5)$ \\
Routine manual and service occupations n (\%) & $15(12.3)$ \\
Student n (\%) & $24(19.7)$ \\
Technical and craft occupations n (\%) & $6(4.9)$ \\
Unemployed n (\%) & \\
HBsAg status & \\
Negative $n(\%)$ & $146(90.1)$ \\
Positive $n(\%)$ & $16(9.9)$ \\
HIV status & \\
Negative $n(\%)$ & $154(95.1)$ \\
Positive $n(\%)$ & $8(4.9)$ \\
\hline
\end{tabular}

a One participant could not provide information on his occupation

b One participant did not agree to be screened for HBsAg and HIV
HIV status, alcohol use and median liver marker enzymes (AST and ALT) between active and recovered HCV infected individuals. The active $\mathrm{HCV}$ infected participants had significantly higher AST ( $35 \mathrm{U} / \mathrm{L})$ and ALT (46 $\mathrm{U} / \mathrm{L})$ compared to those in the recovery state $(\mathrm{P}<0.001)$.

\section{Cytokine responses}

In order to determine the variation in the levels of cytokine among study participants, serum samples were analysed for Th1 (IL-2, IFN gamma and TNF alpha), Th2 (IL-5), Th17 (IL-17A) and Treg (IL-10) cytokines. From the analysis, anti-HCV positive participants who had recovered from the infection had significantly higher [67.2 (50.6-113.1) pg/ml] concentration of IL-10 compared to those with active infection (48.5 (30.3-63.2) $\mathrm{pg} / \mathrm{ml}) \mathrm{p}=0.012$. All other cytokines were similar for the two groups. The comparison in levels of cytokines between recovered and active $\mathrm{HCV}$ infected participants are shown in Table 2.

\section{Discussion}

Acute infection with $\mathrm{HCV}$ often begins as asymptomatic and a large proportion of these infected participants are not able to recover completely. They enter into the chronic phase with active infection. The exact

Table 2 Characteristics and immunological parameters of active and recovered HCV participants

\begin{tabular}{|c|c|c|c|}
\hline & Recovered HCV $(\mathrm{N}=41)$ & Active HCV $(\mathrm{N}=122)$ & $P$ value \\
\hline Sex & & & 0.293 \\
\hline Female (\%) & $13(31.7)$ & $52(42.6)$ & \\
\hline Male (\%) & $28(68.3)$ & $70(57.4)$ & \\
\hline Age (mean, SD) & $32(26,38)$ & $35(29,43.8)$ & 0.069 \\
\hline HBsAg status & & & 0.546 \\
\hline Negative (\%) & $35(87.5)$ & $111(91)$ & \\
\hline Positive (\%) & $5(12.5)$ & $11(9)$ & \\
\hline HIV status & & & 0.681 \\
\hline Negative (\%) & $39(97.5)$ & $115(94.3)$ & \\
\hline Positive (\%) & $1(2.5)$ & $7(5.7)$ & \\
\hline Alcohol use & & & 0.551 \\
\hline No (\%) & $35(85.4)$ & $97(79.5)$ & \\
\hline Yes (\%) & $6(14.6)$ & $25(20.5)$ & \\
\hline AST (median, IQR) U/L & $26(14.2,31)$ & $35(25,55)$ & $<0.001^{*}$ \\
\hline ALT (median, IQR) U/L & $27(7.2,41.5)$ & $46(23,70)$ & $<0.001^{*}$ \\
\hline IL-2 (pg/ml) & $132.4(71.0-207.1)$ & 138.7 (81.8-199.0) & 0.718 \\
\hline IL-5 (pg/ml) & $44.4(37.7-76.0)$ & $49.7(40.7-73.2)$ & 0.549 \\
\hline IL-10 (pg/ml) & $67.2(50.6-113.1)$ & $48.5(30.3-63.2)$ & 0.012 \\
\hline IL-17A (pg/ml) & $18.6(9.6)$ & $18.2(8.5)$ & $0.874^{* *}$ \\
\hline TNF alpha (ng/L) & $61.6(22.3-99.5)$ & $22.7(0.3-111.9)$ & 0.125 \\
\hline IFN gamma (pg/ml) & $59.4(8.0-194.0)$ & $72.8(34.1-275.8)$ & 0.573 \\
\hline
\end{tabular}

AST Aspartate aminotransferase, ALT Alanine aminotransferase, $H B s A g$ Hepatitis B surface antigen 
mechanisms underlying spontaneous recovery from $\mathrm{HCV}$ is unclear. Therefore, we aimed our study at determining some specific serum cytokines that could play a role in spontaneous recovery from $\mathrm{HCV}$ infection.

We determined levels of T cell cytokines IL-2, IFN- $\gamma$, TNF $\alpha$, IL-5, IL-10 and IL-17A among active HCV participants and HCV spontaneously recovered participants. Our study results showed significantly increased levels of IL-10 among spontaneously HCV recovered participants compared with active HCV infection. IL-10 is known to account for appropriate balance of the $\mathrm{T}$ helper cytokines necessary for the natural elimination of the hepatitis $\mathrm{C}$ viruses. This is consistent with observations made by Mangia et al. and Shaker et al., who demonstrated that heterogeneity in the promoter region as well as SNPs of the IL-10 gene influences the determination of spontaneous or treatment induced favourable outcome of HCV infection [20, 21]. IL-10 produced by stimulated regulatory $\mathrm{T}$ cells regulates $\mathrm{Th} 1$ and Th2 by inhibiting their inflammatory responses [22]. IL10 controls the differentiation and proliferation of $\mathrm{B}$ cells, $\mathrm{T}$ cells, antigen-presenting cells, mast cells and granulocytes but negatively regulates Natural killer cells. IL-10 promotes development of type 2 cytokines by inhibiting IFN- $\gamma$ production [23].

Contrary to our study, Osburn et al. reported decreased levels of IL-10 and IL-2 in individuals who had cleared $\mathrm{HCV}$ infection among high risk adults as compared to those who had chronic infection [24]. This outcome differs from our study possibly due to the study design, differences in the age groups of the study populations, environmental exposures and host genetic make-up. We did not observe differences in the interferon, IL-17 and IL-2 levels detected in the serum of recovered and actively infected subjects. IL-2 is known to function by promoting the differentiation of immature $\mathrm{T}$ cells into effector and regulatory $\mathrm{T}$ cells which may positively affect the outcome of infection. [25, 26]. Interferons exhibit antiviral activity, antiproliferative/antitumor and immunomodulatory effects [27]. Despite the apoptotic signalling pathway induced by TNFa, our study found to not play any role in recovery of $\mathrm{HCV}$ infected participants. This outcome is similar to the studies by Abdou et al. 2015 and Costantini et al. 2010 [28-30]. Sex and age did not show any significant difference among active $\mathrm{HCV}$ infection and spontaneous recovery. This is consistent with observations made by Cho et al. and Kim et al. who could not find any statistically significant role played by sex in spontaneous viral clearance of HCV in a Korean population [31, 32]. Tsui et al. made a similar observation in an adult population [33]. However, Bulteel et al. in their retrospective study identified females within the younger age group showing positive association with spontaneous clearance [34]. The variation could be due to the difference in the geographical location and limited sample size of our study population. In this study there was no statistically significant relationship between spontaneous HCV cleared infection and co-infection with HBV or HIV. But in other studies, co-infection with other viruses had an effect on the natural history of $\mathrm{HCV}$ infections leading to variation in detection of serum nucleic acid levels of HCV RNA [35-42]. The study did not established a significant relationship between alcohol consumption and spontaneous HCV clearance or active infection even though alcohol have some immunosuppressive properties [33, 37, 43]. The outcome of the study suggest that serum levels of AST and ALT could be employed as a predictive measure of the status of $\mathrm{HCV}$ infection in seropositive subjects.

\section{Conclusion}

In the present study, age, sex, co-infection with hepatitis $\mathrm{B}$ or HIV variables were not found to be associated with spontaneous HCV clearance in the selected Ghanaian population. The levels of IL-2, IFN- $\gamma$, TNF $\alpha$, IL-5 and IL$17 \mathrm{~A}$ in the serum of $\mathrm{HCV}$ sero-positive are not associated with active $\mathrm{HCV}$ infection or spontaneously recovered infection. The levels of IL-10 was high in spontaneously recovered $\mathrm{HCV}$ persons, therefore could be explored as a predictive measure of $\mathrm{HCV}$ status in anti-HCV positive persons.

\section{Limitations}

The limitations of this study could be conducting a crosssectional study and the small sample size used. Longitudinal studies that employs a larger population size could provide useful information that would further strengthen the findings of this study.

\section{Abbreviations}

IL: Interleukin; HCV: Hepatitis C virus; GCUC: Garden City University College; KCCR: Kumasi Centre for Collaborative Research in Tropical Medicine; KNUST: Kwame Nkrumah University of Science and Technology; IFN: Interferon gamma; KATH: Komfo Anokye Teaching Hospital; EDTA: Ethylenediaminetetraacetic acid; CHRPE: Committee for Human Research, Publications and Ethics; ELISA: Enzyme linked immunosorbent assay; RNA: Ribonucleic acid; RT-PCR: Real time polymerase chain reaction; HBsAg: Hepatitis C surface antigens; HIV: Human immunodeficiency virus.

\section{Acknowledgements}

The authors thank all the study participants. We are thankful to Professor Jennifer Layden of Loyola University Medical Center, Chicago and her team for the provision of some logistics used in the study. Thanks to Dr. Mrs. Shirley Owusu-Ofori of the Blood Donor Unit, KATH and all the study team members for their cooperation and great support during the study.

\section{Authors' contributions}

DOO was the lead for the study, DOO, RP, MO and MF made conceptual contributions; DOO, RP and FSS designed the methodology of the work; MO, DOO and FSS analysed the study results; DOO and MO drafted the work; RP, MF and 
FSS substantively revised the manuscript. All authors read and approved the final manuscript.

\section{Funding}

This research received no external funding.

\section{Availability of data and materials}

The datasets used and/or analysed during the current study are available from the corresponding author on reasonable request.

\section{Ethics approval and consent to participate}

The Research was performed in accordance with the Declaration of Helsinki. The study obtained written consent from all study participants. Research ethics approval was obtained from Kwame Nkrumah University of Science and Technology and the Komfo Anokye Teaching Hospital research ethics review committee before commencement (Reference; CHRPE/AP/134/13, CHRPE/ AP/443/13 and CHRPE/AP/162/15). Confidentiality of participants information was maintained at each level of the study.

\section{Consent for publication}

Not applicable. There are no details relating to an individual person.

\section{Competing interests}

The authors declare that they have no competing interests" in this section.

\section{Author details}

1 Department of Medical Laboratory Technology, Garden City University College (GCUC), P.O. Box 12775, Kumasi, Ghana. ${ }^{2}$ Kumasi Centre for Collaborative Research in Tropical Medicine (KCCR), Kwame Nkrumah University of Science and Technology (KNUST), PMB, KNUST, Kumasi, Ghana. ${ }^{3}$ Department of Medical Diagnostics, Kwame Nkrumah University of Science and Technology (KNUST), University Post Office, Kumasi, Ghana. ${ }^{4}$ Department of Medicine, Komfo Anokye Teaching Hospital, Kwame Nkrumah University of Science and Technology, University Post Office, Kumasi, Ghana. ${ }^{5}$ Department of Molecular Medicine, Kwame Nkrumah University of Science and Technology, Kumasi, Ghana.

Received: 26 June 2020 Accepted: 28 September 2020 Published online: 07 October 2020

\section{References}

1. Thomas DL. Global control of hepatitis C: Where challenge meets opportunity. Nat Med. 2013;19(7):850-8.

2. WHO. Hepatitis C - Fact Sheet. 2017. p. October.

3. Chen AY, Hoare M, Shankar AN, Allison M, Alexander GJM, MichalakTI, et al. Persistence of hepatitis $C$ virus traces after spontaneous resolution of hepatitis C. PLoS ONE. 2015;10(10):1-16.

4. Zhang M, Rosenberg PS, Brown DL, Preiss L, Konkle BA, Eyster ME, et al. Correlates of spontaneous clearance of hepatitis $C$ virus among people with hemophilia. Vol. 107, Blood. 2006. p. 892-7.

5. Shepard CW, Finelli L, Alter MJ. Global epidemiology of hepatitis C virus infection. Lancet Infect Dis. 2005. 5(9):558-67. http://www.ncbi.nlm.nih. gov/pubmed/16122679.

6. Arcjentini ARC, Kouruma F, Chionne P, Ucjo ED, Sabbatanp ESSDS, Rapicetta M. Heterogeneity of hepatitis C virus genotype 2 variants in West Central Africa (Guinea Conakry). J Gen Virol. 1996;77:2073-6.

7. Genovese D, Dettori S, Argentini C, Villano U, Chionne P, Angelico M, et al. Molecular epidemiology of hepatitis $C$ virus genotype 4 isolates in egypt and analysis of the variability of envelope proteins E1 and E2 in patients with chronic hepatitis. J Clin Microbiol. 2005;43(4):1902.

8. Menendez C, Sanchez-tapias JM, Kahigwa E, Mshinda H, Costa J, Vidal J, et al. Prevalence and mother-to-infant transmission of hepatitis viruses $B$, C, and E in Southern Tanzania. J Med Virol. 1999;58(3):215-20.

9. Njouom R, Pasquier C, Ayouba A, Tejiokem MC, Vessiere A, Mfoupouendoun J, et al. Low Risk of mother-to-child transmission of hepatitis C virus in Yaode, Cameroo: The ANRS 1262 Study. Am Soc Trop Med Hyg. 2005;73(2):460-6.

10. Averhoff FM, Glass N, Holtzman D. Global burden of hepatitis C: considerations for healthcare providers in the United States. Clin Infect Dis
[Internet]. 2012 Jul [cited 2013 Jun 10]; 55(Suppl 1):S10-5. http://www. ncbi.nlm.nih.gov/pubmed/22715208.

11. Adjei AA, Armah HB, Gbagbo F, Ampofo WK, Quaye IKE, Hesse IFA, et al. Prevalence of human immunodeficiency virus, hepatitis $B$ virus, hepatitis $C$ virus and syphilis among prison inmates and officers at Nsawam and Accra Ghana. J Med Microbiol. 2006;55(5):593-7.

12. Candotti D, Temple J, Sarkodie F, Allain J. Frequent recovery and broad genotype 2 diversity characterize hepatitis C virus infection in Ghana West Africa. J Virol. 2003;77(14):7914-23.

13. Madhava V, Burgess C, Drucker E. Review Epidemiology of chronic hepatitis $C$ virus infection in sub-Saharan Africa. Lancet Infect Dis. 2002;2(5):293-302.

14. Nelson PK, Mathers BM, Cowie B, Hagan H, Jarlais D, Horyniak D, et al. Global epidemiology of hepatitis B and hepatitis C in people who inject drugs : results of systematic reviews. Lancet. 2010;378(9791):571-83. https://doi.org/10.1016/S0140-6736(11)61097-0.

15. Sarkodie F, Adarkwa M, Adu-Sarkodie Y, Candotti D, Acheampong JW, Allain JP. Screening for viral markers in volunteer and replacement blood donors in West Africa. Vox Sang. 2001;80(3):142-7.

16. Kew MC. Epidemiology of hepatocellular carcinoma in sub-Saharan Africa. Ann Hepatol. 2013;12(2):173-82.

17. Petruzziello A. Epidemiology of Hepatitis B Virus (HBV) and Hepatitis C Virus (HCV) Related Hepatocellular Carcinoma. Open Virol J [Internet]. 2018. 12(Suppl-1, M3):26-32. http://benthamopen.com/FULLTEXT/ TOVJ-12-26.

18. Mittal S, El-Serag HB. Epidemiology of HCC: Consider the Population. J Clin Gastroenterol. 2013;47:1-10.

19. Coppola N, Pisapia R, Marrocco C, Martini S, Vatiero LM, Messina $\checkmark$, et al. Anti-HCV IgG avidity index in acute hepatitis C. J Clin Virol. 2007:40(2):110-5.

20. Mangia A, Santoro R, Piattelli M, Pazienza V, Grifa G, lacobellis A, et al. IL-10 haplotypes as possible predictors of spontaneous clearance of HCV infection. Cytokine. 2004;25(3):103-9.

21. Shaker OG, Nassar YH, Nour ZA, El Raziky M. Single-nucleotide polymorphisms of IL-10 and IL-28B as predictors of the response of IFN therapy in HCV genotype 4-infected children. J Pediatr Gastroenterol Nutr. 2013;57(2):155-60.

22. Moore KW, de Waal Malefyt R, Coffman RL, O'Garra A. Interleukin-10 and the interleukin-10 receptor. Annu Rev Immunol. 2001;19:683-765.

23. Ouyang W, Rutz S, Crellin NK, Valdez PA, Hymowitz SG. Regulation and functions of the IL-10 family of cytokines in inflammation and disease. Annu Rev Immunol. 2011;29:71-109.

24. Osburn WO, Levine JS, Chattergoon MA, Thomas DL, Cox AL. Anti-inflammatory cytokines, pro-fibrogenic chemokines and persistence of acute HCV infection. J Viral Hepat. 2013;20(6):404-13.

25. Capobianco MP, Cassiano GC, Furini AA da C, Melo LMS de, Machado CRBD, Dantas RL, et al. Human Interleukin 2 (IL-2) Promotion of Immune Regulation and Clinical Outcomes: A Review. J Cytokine Biol. 2016. 1(109):14-7.

26. Schlaak JF, Schramm C, Radecke K, zum Buschenfelde K-HM, Gerken G. Sustained suppression of HCV replication and inflammatory activity after interleukin-2 therapy in patients with HIV/hepatitis C virus coinfection. J Acquir Immune Defic Syndr. 2002. 29(2):145-8.

27. Fensterl V, Sen GC. Interferons and viral infections. BioFactors. 2009;35(1):14-20. https://doi.org/10.1002/biof.6.

28. Abdou AG, Asaad NY, Ehsan N, Eltahmody M, El-Sabaawy MM, Elkholy S, et al. The role of IL-28, IFN-gamma, and TNF-alpha in predicting response to pegylated interferon/ribavirin in chronic HCV patients. APMIS. 2015;123(1):18-27.

29. Costantini S, Capone F, Guerriero E, Maio P, Colonna G, Castello G. Serum cytokine levels as putative prognostic markers in the progression of chronic HCV hepatitis to cirrhosis. Eur Cytokine Netw. 2010;21(4):251-6.

30. Pompili M, Biolato M, Miele L, Grieco A. Tumor necrosis factor-alpha inhibitors and chronic hepatitis $\mathrm{C}$ : a comprehensive literature review. World J Gastroenterol. 2013;19(44):7867-73.

31. Kim JY, Won JE, Jeong S-H, Park SJ, Hwang SG, Kang S-K, et al. Acute hepatitis $C$ in Korea: different modes of infection, high rate of spontaneous recovery, and low rate of seroconversion. J Med Virol. 2011;83(7):1195-202.

32. Cho Y-K, Kim YN, Song B-C. Predictors of spontaneous viral clearance and outcomes of acute hepatitis C infection. Clin Mol Hepatol. 2014. 
20(4):368-75. http://www.pubmedcentral.nih.gov/articlerender.fcgi?artid $=4278068 \&$ tool $=$ pmcentrez\&rendertype $=$ abstract.

33. Tsui Jl, Mirzazadeh A, Hahn JA, Maher L, Bruneau J, Grebely J, et al. The effects of alcohol on spontaneous clearance of acute hepatitis $C$ virus infection in females versus males. Drug Alcohol Depend. 2016;169:156-62.

34. Bulteel N, Partha Sarathy P, Forrest E, Stanley AJ, Innes H, Mills PR, et al. Factors associated with spontaneous clearance of chronic hepatitis $C$ virus infection. J Hepatol. 2016;65(2):266-72.

35. Hernandez and Sherman. HIV/HCV coinfection natural history and disease progression, a review of the most recent literature. Curr Opin HIV AIDS. 2011;6(6):478-82.

36. Mastroianni CM, Lichtner M, Mascia C, Zuccalà P, Vullo V. Molecular mechanisms of liver fibrosis in HIV/HCV coinfection. Int J Mol Sci. 2014;15(6):9184-208.

37. Piasecki BA, Lewis JD, Reddy KR, Bellamy SL, Porter SB, Weinrieb RM, et al. Influence of alcohol use, race, and viral coinfections on spontaneous HCV clearance in a US veteran population. Hepatology. 2004;40(4):892-9.

38. Nguyen LH, Ko S, Wong SS, Tran PS, Trinh HN, Garcia RT, et al. Ethnic differences in viral dominance patterns in patients with hepatitis B virus and hepatitis C virus dual infection. Hepatology. 2011;53(6):1839-45.

39. Liu C-J. Treatment of patients with dual hepatitis C virus and hepatitis B virus infection: Resolved and unresolved issues. J Gastroenterol Hepatol [Internet]. 2014. 29(1):26-30. http://doi.wiley.com/10.1111/jgh.12421.
40. Hung C-H, Lu S-N, Wang J-H, Hu T-H, Chen C-H, Huang C-M, et al. Sustained HCV clearance by interferon-based therapy reduces hepatocellular carcinoma in hepatitis B and C dually-infected patients. Antivir Ther. 2011;16(7):959-68.

41. Arends JE, van Assen S, Stek CJ, Wensing AM, Fransen JH, Schellens IM, et al. Pegylated interferon-alpha monotherapy leads to low response rates in HIV-infected patients with acute hepatitis C. Antivir Ther. 2011;16(7):979-88.

42. Matthews GV, Dore GJ. HIV and hepatitis C coinfection. J Gastroenterol Hepatol. 2008;23(7 Pt 1):1000-8.

43. Szabo G, Mandrekar P. A recent perspective on alcohol, immunity, and host defense. Alcohol Clin Exp Res. 2009;33(2):220-32. https://doi.org/10. 1111/j.1530-0277.2008.00842.x.

44. Layden JE, Phillips RO, Owusu-Ofori S, Sarfo FS, Kliethermes S, Mora N, et al. High frequency of active HCV infection among seropositive cases in West Africa and evidence for multiple transmission pathways. Clin Infect Dis. 2015;60(7):1033-41.

\section{Publisher's Note}

Springer Nature remains neutral with regard to jurisdictional claims in published maps and institutional affiliations.
Ready to submit your research? Choose BMC and benefit from:

- fast, convenient online submission

- thorough peer review by experienced researchers in your field

- rapid publication on acceptance

- support for research data, including large and complex data types

- gold Open Access which fosters wider collaboration and increased citations

- maximum visibility for your research: over $100 \mathrm{M}$ website views per year

At BMC, research is always in progress.

Learn more biomedcentral.com/submissions 